\title{
Application of PhET Simulation Media in Physics Learning During a Pandemic Covid-19
}

\author{
Elsa Febriani Sari ${ }^{1}$, Dewi Khairani ${ }^{2}$, Imam Subchi ${ }^{3}$, Yusuf Durachman ${ }^{4}$, \\ Agus Rifai ${ }^{5}$, Dede Rosyada ${ }^{6}$ \\ \{elsa.febrianisari17@mhs.uinjkt.ac.id¹, dewi.khairani@uinjkt.ac.id²,imam.subchi@uinjkt.ac.id², \\ yusuf_durachman@uinjkt.ac.id ${ }^{4}$, agus.rifai@uinjkt.ac.id ${ }^{5}$,dede.rosyada@uinjkt.ac.id ${ }^{6}$ \}
}

Syarif Hidayatullah State Islamic University of Jakarta, Indonesia ${ }^{1,2,3,4,5,6}$

\begin{abstract}
The coronavirus outbreak has made teaching and learning activities that should be carried out in schools now must be carried out at home with controlled by teachers and parents. Many students complain that they are burdened by many tasks and their low ability to solve problems - especially in physics. This difficulty can be caused by several factors, one of which is a lack of understanding of the physics concepts being studied. The purpose of writing this article is to identify how the application of PhET simulation media in the physics learning process during a pandemic. The method used is the descriptive qualitative method with interview techniques. Based on the results of interviews and data analysis, it can be concluded that the PhET simulation media can be used as a reference medium for learning physics during this pandemic. This is because the PhET simulation media can increase students' interest in physics. The abstract needs to summarize the content of the paper.
\end{abstract}

Keywords: PhET simulation media, physics learning, Covid-19.

\section{Introduction}

In the last few months, the world community is facing the Coronavirus outbreak. This virus originated in Wuhan, China. This virus can be transmitted from human to human and has spread widely. Recently, WHO has confirmed that this virus can spread through the air. As of August 11, 2020, there were 19,936,210 cases and 732,499 deaths from 216 countries, including Indonesia.[1]

This condition cannot be ignored, because this virus is quite dangerous and deadly. Therefore, the Indonesian government has implemented Large-Scale Social Restrictions (LSRR) (Indonesian: Pembatasan Sosial Berskala Besar or PSBB) to break the chain of spreading the Coronavirus.

The implementation of the PSBB is believed to be the most effective way to reduce the rate of transmission of the Coronavirus. This can be seen from the steps taken by the government, namely by appealing to the public to impose restrictions on activities in certain sectors including the education sector.[2]

Due to restrictions on activities in the education sector, teaching and learning activities $(\mathrm{KBM})$ is carried out at home, but there is still controlled by teachers and parents. In this distance learning, the interaction between teachers and students occurs virtually using tools or technology such as computers, notebooks, or cell phones. 
Situations and conditions like this may not be conducive because both teachers and students have to adapt first. Not a few students also complain because they are burdened by many tasks. Especially in learning physics, students' problem-solving ability is still low. The difficulty in solving this problem can be caused by several factors, one of which is a lack of understanding of the physics concepts being studied.[3]

Physics is a way to understand how this universe works. Physics is not just equations and numbers, so it is very important to understand the concepts qualitatively. One way to understand this concept is to do a practicum. Because the more the senses are used to receive something, the easier it is to remember and understand.[4] But the current pandemic situation has eliminated all of that. A practicum that should be done in the laboratory cannot now be implemented.

However, in the era of the industrial revolution 4.0, the development of the world of technology and information has been very rapid so that it can provide an alternative substitute for practicum in the laboratory to help students understand concepts, one of which is by using PhET (Physics Education and Technology) simulation media.

This PhET simulation media was developed by Katherin Perkins et al from the University of Colorado, United States. This media can be run directly from a website using a standard web browser or it can download and install an entire website (currently around $60 \mathrm{MB}$ ) for offline use.[5]

This PhET simulation consists of objects that are invisible to the real world, such as atoms, electrons, photons, and electric fields. Students can interact through pictures and intuitive controls which include click and drag, slide switches, and buttons. With the animation presented, students can investigate the cause and effect of the phenomena presented so that it can help students visually understand physics concepts.[5]

Based on the explanation above, the purpose of this study was to identify how the application of PhET simulation media in the physics learning process during a pandemic.

\section{Literature Review}

A virtual laboratory is interactive multimedia which consists of various heterogeneous formats including text, hypertext, sound, images, animation, video, and graphics. This virtual laboratory can be used to describe a phenomenon that cannot be seen in real situations. The development of a virtual laboratory is expected to be able to overcome learning difficulties experienced by students, such as procuring tools and materials that are commonly used for practicum activities in the laboratory.[6] Virtual laboratories can also increase student activity. Media-based learning Virtual laboratories provide opportunities for students to explore, thus enabling them to always be active, not just listening and taking notes.[7] One of the laboratories that can be used is the PhET simulation media.

PhET simulation media is an interactive simulation media on the internet using the Java programming language and flash. This PhET simulation media was developed by Katherin Perkins et al, a team from the University of Colorado in the United States. This media can be run directly from a website using a standard web browser or it can download and install an entire website (currently around $60 \mathrm{MB}$ ) for offline use.[5]

The PhET simulation medium provides an inadequate range of experiments for the laboratory. The advantages of this PhET simulation media include being able to perform 
experiments that cannot be carried out by real tools. Besides, this media is also designed to make it easier to analyze a concept, especially physics in the form of a simulation.[6]

Several studies have been conducted regarding the application of PhET simulation media in the physics learning process. According to research conducted by Masita et al. Using the Nonequivalent Control Group Design, which is a study consisting of an experimental class taught using PhET Simulation and a control class taught without using PhET Simulation. This study revealed that in the experimental class there was an increase in understanding of physics concepts by 0.62 , while in the control class it was only 0.13 . So it can be said that using the PhET simulation can improve students' understanding of physics concepts. However, there are shortcomings in this PhET simulation media, namely not all students already have an Android smartphone, which causes the student to be slow to understand the simulation.[8]

Anwar et al's research conducted testing of PhET media with a photoelectric effect simulation specification as an experimental tool to determine the Planck constant (h) and show whether the kinetic energy of photoelectrons depends on light intensity or not. The result of this research is that the PhET simulation media can provide a good level of accuracy in determining the Planck constant of $(6.80 \pm 0.09) \times 10-34$ Js. Meanwhile, the photoelectron kinetic energy is shown to be independent of light intensity. So it can be concluded that the PhET media can prove the Planck constant value and help in understanding abstract concepts and theories such as the photoelectric effect phenomenon easily, quickly, and practically.[9]

PhET simulation media can also improve students' critical thinking skills, such as research conducted by Alifiyanti and Ishafit. This study used a classroom action research method with a guided inquiry learning model. The results of this study reveal that the application of guided inquiry learning models assisted by PhET Simulation can improve students' critical thinking skills, especially on the subject of the kinetic theory of gases. Through Phet Simulation, students become more active and interested in studying physics and also better understand the material and its application in everyday life.[10]

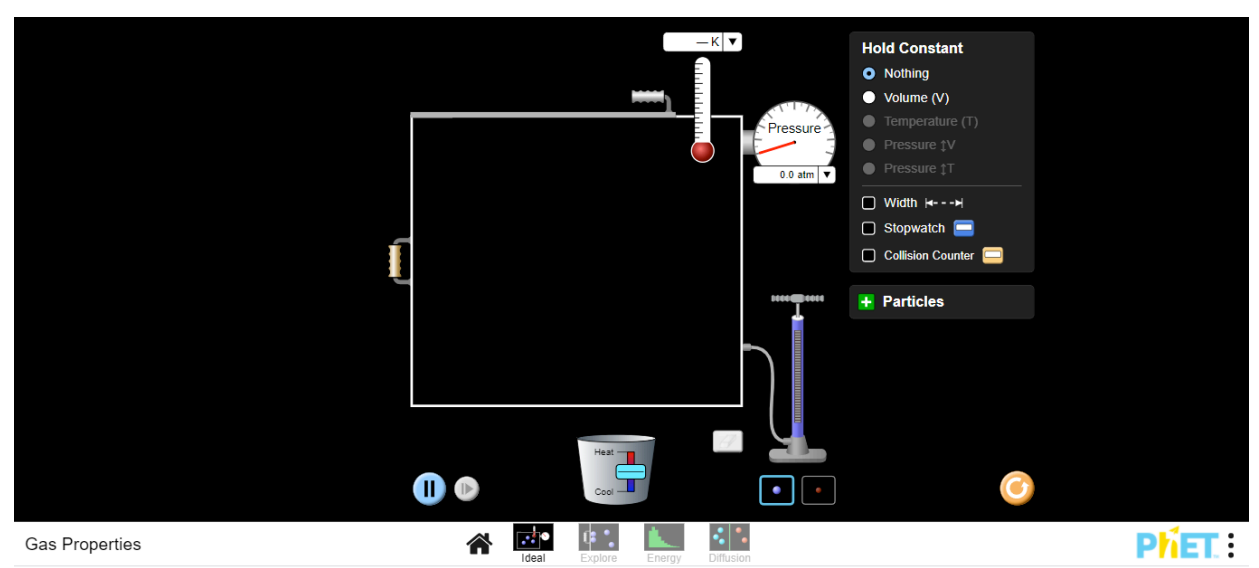

Fig. 1. Simulation of Gas Properties.[11]

Besides being able to improve students' critical thinking skills, learning physics with the help of PhET simulation media can also increase student motivation. This is in line with research conducted by Thohari et al. The result of the research is that physics learning by applying a generative model will be more effective in increasing student motivation if the choice of media must also be considered, one of which is the PhET media. PhET interactive 
simulations are animated, interactive, and play-like simulations in which students learn by exploring.[12]

\section{Research Method}

In this study, researchers used descriptive qualitative research methods. This data collection technique is done by interview. The data from the interviews were then analyzed using qualitative descriptive analysis, that is, through the data obtained from the interview results, they are described as a whole.

Data analysis began by conducting in-depth interviews with the informants. After conducting the interview, the researcher made a transcript of the interview results. After the researcher wrote the results of the interview into the transcript, then the researcher made data reduction through abstraction, which is taking data that is by the research context and ignoring unnecessary data.

The informants in this study were 3 people in twelfth grade at one of the senior high school in West Jakarta. This resource person tried the PhET simulation media first, then gave their opinion about this media.

The descriptive data analysis model used in this research, described in Fig.1 below.

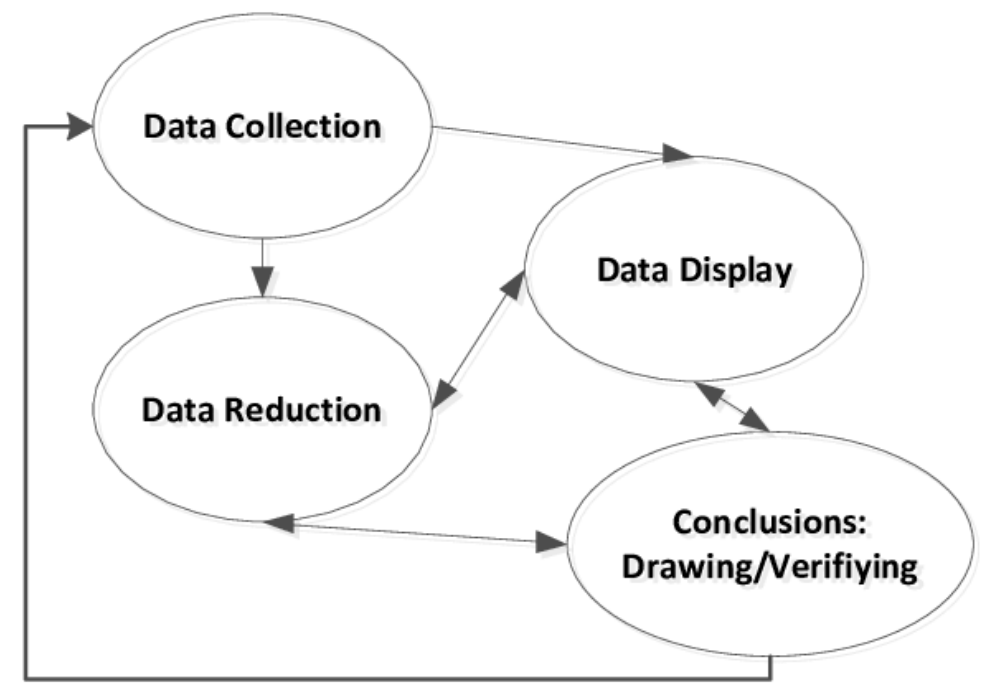

Fig. 2. Qualitative descriptive data analysis model of Miles dan Huberman.[13]

\section{Results and Discussion}

This discussion was conducted based on the results of interviews with several students who had used the PhET simulation media.

The learning process will be more meaningful if students are interested in participating in learning. PhET simulation media is a medium that can help develop students' abilities and 
skills and can also increase student interest in learning. This statement is in line with research conducted by Wieman and Perkins (2006) that the use of PhET simulations in learning often leads to questions that train students' higher-order thinking skills.[14] And research by Saregar (2016) states that the application of PhET simulation media through a student-oriented approach can increase student interest in learning physics.[15]

According to the informants, this PhET simulation media has a simple, colorful, and attractive appearance because it contains illustrations and required variables. The resource persons were interested in using this PhET simulation media in the physics learning process, especially in a pandemic like now. Because usually the teacher only provides material in the form of PowerPoint, whereas when using the PhET simulation media the user can change the available variables so that it doesn't seem boring when learning.

Apart from that, according to the informants, the PhET simulation media is also very easy to access and free. The PhET simulation can be used for free both online and offline so it is quite easy to use in class. The simulation is written in java and flash form so that it can be run with a standard web browser as long as the java and flash programs are installed on the computer being used. To ensure the effectiveness of teaching and its usefulness, all simulations have been tested and evaluated.[16]

The most important thing in using the PhET simulation media is that the PhET simulation media can improve students' understanding of physics concepts. The informants can conclude the relationship between variables by themselves by changing one variable and seeing its impact directly on other variables. This is in line with the statement that the PhET simulation media was developed to help students visually understand physics concepts using dynamic graphics that can explicitly bring to life the visual and conceptual models used by expert physicists.[5]

This PhET simulation media can also clarify abstract physics concepts. This is because the PhET simulation media can visualize the physical mechanism model from a phenomenon to the micro-level. For example, in static electricity, the source understands better because they can see positive and negative charges directly and the phenomenon of attraction and repulsion between these charges.

However, besides the advantages of the PhET simulation media that have been described above, some things need to be remembered and become an important note, namely that before using this PhET simulation media, students need to be given instructions in advance so as not to get confused. Or in other words, in implementing the use of simulation media, it needs to be accompanied by an appropriate learning model or method to achieve a learning goal. Because the learning media only functions as supporting material for student learning, it is not a learning medium that is studied independently by students.[17]

\section{Conclusion}

From the results of the research and analysis that has been done, it can be concluded that students are interested in using PhET simulation media in learning physics during this pandemic. This is because the PhET simulation media has an attractive appearance and easy access, the most important thing is that this media can improve students' understanding of physics concepts - especially for abstract physics concepts. Therefore, learning physics with the help of PhET simulation media during this pandemic can be used as a reference medium for accompanying models or learning methods. 
Acknowledgment. This paper was supported by PPM UIN Syarif Hidayatullah Jakarta for KKN-DR year 2020. 


\section{References}

[1] World Health Organization, "WHO Coronavirus Disease (COVID-19) Dashboard," World Health Organization, 2020. .

[2] R. Nasruddin and I. Haq, "Pembatasan Sosial Berskala Besar (PSBB) dan Masyarakat Berpenghasilan Rendah," SALAM J. Sos. dan Budaya Syar-i, vol. 7, no. 7, 2020, doi: 10.15408/sjsbs.v7i7.15569.

[3] R. Azizah, L. Yuliati, and E. Latifah, "KESULITAN PEMECAHAN MASALAH FISIKA PADA SISWA SMA,” J. Penelit. Fis. dan Apl., 2015, doi: 10.26740/jpfa.v5n2.p44-50.

[4] D. Novitasari, "PENGARUH PENGGUNAAN MULTIMEDIA INTERAKTIF TERHADAP KEMAMPUAN PEMAHAMAN KONSEP MATEMATIS SISWA," FIBONACCI J. Pendidik. Mat. dan Mat., 2016, doi: 10.24853/fbc.2.2.8-18.

[5] D. R. Rizaldi, A. W. Jufri, and Jamal, "PhET : SIMULASI INTERAKTIF DALAM PROSES PEMBELAJARAN FISIKA," J. Ilm. Profesi Pendidik., vol. 5, no. 1, pp. 10-14, 2020, doi: 10.29303/jipp.v5i1.103.

[6] J. Handika, S. D. Fatmaryanti, Winarti, I. S. Budiarti, N. Khasanah, and Viyanti, PEMBELAJARAN SAINS DI ERA AKSELERASI DIGITAL. Magetan: CV. AE MEDIA GRAFIKA, 2020.

[7] I. Yusuf, W. Widyaningsih, and D. Purwati, "Pengembangan Perangkat Pembelajaran Fisika Modern Berbasis Media Laboratorium Virtual Berdasarkan," Pancaran, vol. 4, no. 2, pp. 189-200, 2015.

[8] S. I. Masita, P. B. Donuata, A. A. Ete, and M. E. Rusdin, "Penggunaan Phet Simulation Dalam Meningkatan Pemahaman Konsep Fisika Peserta Didik," J. Penelit. Pendidik. Fis., 2020, doi: 10.36709/jipfi.v5i2.12900.

[9] K. Anwar, M. Isnaini, and L. S. (Universitas M. M. Utami, "EKSPERIMEN EFEK FOTO LISTRIK BERBASIS SIMULASI PhET," J. Kajian, Penelit. dan Pengemb. Kependidikan, vol. 4, no. 2, pp. 9-15, 2018.

[10] I. F. Alifiyanti and Ishafit, "Penerapan model pembelajaran inkuiri terbimbing berbantuan PhET Simulation untuk meningkatkan kemampuan berpikir kritis siswa pada pokok bahasan teori kinetik gas di MAN 3 Ngawi,” Pros. Semin. Nas. Quantum, vol. 25, pp. 392-400, 2018.

[11] University of Colorado Boulder, "PhET: Free online physics, chemistry, biology, earth science and math simulations," PhET Colorado Simulations, 2002. .

[12] U. H. Thohari, M. Madlazim, and Y. S. Rahayu, "Developing Learning Tools Guided Discovery Models Assisted PhET Simulations For Trainning Critical Thinking Skills High School Students," Int. J. Multicult. Multireligious Underst., vol. 6, no. 4, p. 390, 2019, doi: 10.18415/ijmmu.v6i4.1008.

[13] M. A. Miles, "Miles and Huberman (1994)- Chapter 4.pdf," in Qualitative Data Analysis: An Expanded Sourcebook, 1994.

[14] K. Perkins et al., "PhET: Interactive Simulations for Teaching and Learning Physics," Phys. Teach., 2006, doi: 10.1119/1.2150754.

[15] A. Saregar, "Pembelajaran Pengantar Fisika Kuantum dengan Memanfaatkan Media Phet Simulation dan LKM Melalui Pendekatan Saintifik: Dampak pada Minat dan Penguasaan Konsep Mahasiswa," J. Ilm. Pendidik. Fis. Al-Biruni, 2016, doi: 10.24042/jpifalbiruni.v5i1.105. 
[16] C. L. Harum, Yusrizal, M. Syukri, and C. Nurmaliah, "Pengaruh Model Pembelajaran Generatif Berbasis PhET Terhadap Keterampilan Berpikir Kritis dan Motivasi Belajar Siswa pada Materi Gelombang," J. Pendidik. Sains Indones. (Indonesian J. Sci. Educ., vol. 8, no. 2, pp. 164174, 2020, doi: 10.24815/jpsi.v8i2.15776.

[17] M. Miftah, "FUNGSI, DAN PERAN MEDIA PEMBELAJARAN SEBAGAI UPAYA PENINGKATAN KEMAMPUAN BELAJAR SISWA,” $J$. Kwangsan, 2013, doi: 10.31800/jurnalkwangsan.v1i2.7. 